\title{
International Personality Rights AND Holographic Portrayals
}

\author{
CAROL J. GREER ${ }^{*}$
}

\section{INTRODUCTION}

Americans see privacy as a protection of liberty, while Europeans see it as a protection of dignity. ${ }^{1}$

When considering personality rights in the United States, the only consistent conclusion is that it is not clear. ${ }^{2}$ Personality rights in the United States ("U.S.") are protected by a "patchwork" of publicity and privacy torts, which overlap. ${ }^{3}$ Free speech is complicated by progressive technology, media sharing and converting, and the prevalent access to the internet, defeating the protection of the right of personality in the U.S. by increasing holes in the human rights of dignity, self-determination, and privacy. ${ }^{4}$

This Note identifies the lack of coverage for the right of personality for U.S. citizens and boldly proposes a partial constraint on the esteemed First Amendment. The right of personality is an umbrella of human rights for dignity, privacy, and self-determination exemplified in the European Convention on Human Rights and certain aspects of German and French law. ${ }^{5}$ The right of personality is interwoven throughout European law, which the U.S. could incorporate while still upholding the First Amendment. ${ }^{6}$ The U.S. does not acknowledge the right of personality per se, but does recognize a legal patchwork of defeasible state law rights of publicity and privacy tort claims, such as misappropriation, false light, defamation, and others. ${ }^{7}$

* J.D., Indiana University Robert H. McKinney School of Law, 2017; B.A. Marketing, Indiana University Kelley School of Business 2013.

1. Robin D. Barnes, Outrageous Invasions 15 (2010).

2. J. Eugene Salomon, Jr., The Right of Publicity Run Riot: The Case for a Federal Statute, 60 S. CAL. L. REV. 1179, 1179 (1986).

3. Id.; see generally Christopher McCrudden, Human Dignity and Judicial Interpretation of Human Rights, 19 EUR. J. INT'L L. 655, 656-63 (2008).

4. See generally David Ardia, Bloggers and Other Online Publishers Face Increasing Legal Threats, POYNTER (Sept. 22, 2008), http://www.poynter.org/2008/bloggers-and-other-onlinepublishers-face-increasing-legal-threats/91639/.

5. Johann Neethling, Personality Rights: A Comparative Overview, 38 CoMP. \& INT'L L.J. S. AFRICA 210, 211-13 (2005).

6. Personality Rights in European Tort Law 3 (Gert Bruggemerier, Aurelia Colombi Ciacchi, \& Patrick O’Callaghan, eds., 2010), ProQuest.

7. See Ardia, supra note 4 ("the Internet, after all, is available to anyone who wishes to connect to the network, and even the smallest blog or most esoteric discussion forum has the potential to reach hundreds of millions of people throughout the world."); The group of claims listed here is not inclusive and will be referred to as right of personality claims, personality torts, or right of personality state claims, among other variations; however, personality rights are 
Without acknowledging a right of personality, the U.S. cannot adjust to the rapid evolution of technology and media. The Constitution did not intend the First Amendment to allow the loss of human dignity imbedded in personalities of U.S. citizens. ${ }^{8}$ According to J. Thomas McCarthy, the leading author on the subject, the right of publicity is:

the inherent right of every human being to control the commercial use of his or her identity. This legal right is infringed by unpermitted use which damages the commercial value of this inherent human right of identity and which is not immunized by principles of free press and free speech. ${ }^{9}$

However, identifying what is "immunized by principles of free press and free speech" is like this riddle:

Three men go to stay at a motel, and the man at the desk charges them $\$ 30.00$ for a room. They split the cost ten dollars each. Later the manager tells the desk man that he overcharged the men; that the actual cost should have been $\$ 25.00$. The manager gives the bellboy $\$ 5.00$ and tells him to give it to the men.

The bellboy, however, decides to cheat the men and pockets $\$ 2.00$, giving each of the men only one dollar.

Now each man has paid $\$ 9.00$ to stay in the room and $3 \times \$ 9.00=$ $\$ 27.00$. The bellboy has pocketed $\$ 2.00$. $\$ 27.00+\$ 2.00=\$ 29.00-$ so where is the missing $\$ 1.00 ?^{10}$

It does not add up because the items added together are not correct. Similarly, the balancing tests for the state right of publicity against federally protected free speech leave missing pieces.

This Note proposes that there should be no First Amendment exception to the general requirement of consent to use one's image when a realistic hologram is modeled after a human, alive or dead, celebrity or not. Additionally, the State's right of publicity protections should be unified by implementing common European principles onto the U.S. foundation. It is uncontested that the right of

sometimes interchanged with the right of publicity in other scholarship.

8. P. A. Madison, Original Meaning: Freedom of Speech or of the Press, THE FEDERALIST BLOG (Oct. 18, 2008), http://www.federalistblog.us/2008/10/freedom_of_speech_and_of_the_ press/ ("Freedom of speech and of the press served one purpose in America: To remove the fear of the common law doctrine of seditious libel so citizens could freely speak or publish without license their grievances against public policy or conduct of public officials. One of the distasteful things found under the common law was the government practice of criminalizing or shielding itself through requiring license to publish of any criticism it felt made people dissatisfied with their government or government established religion.").

9. J. Thomas McCarthy, Treatise, Preliminary Materials, Rights of Publicity And PRIVACY (2016).

10. The Missing Dollar, The Math Forum @ DreXel, http://mathforum.org/dr.math/ faq/faq.missing.dollar.html (last visited Jan. 10, 2016). 
publicity in the U.S. is complicated and inconsistently implemented. ${ }^{11}$

Though the right of publicity is a fairly new area of law, a great deal of ink was spilled by preceding scholars and professionals in favor of a federal right of publicity. ${ }^{12}$ This Note supports that premise and further recommends an overarching federally recognized right of personality, which encompasses not only privacy or economic interests in one's own image, but primarily selfdetermination and dignity.

Besides the complexity of the right of publicity in the US, this Note faces another challenge which pertains to encompassing rapidly evolving and emerging technology. A digital representation, or "hologram," of a person can be manufactured, be projected into a real environment, and be so realistic that the human eye is fooled to accept it as a real person. ${ }^{13}$ The digital human can also be animated by digital programming to mimic the motion and sound of a person, essentially turning it into a virtual clone. ${ }^{14}$ The term "hologram," as it is used in this Note, is a misnomer. ${ }^{15}$ Hologram technology is moving from the live stage to home entertainment which enhance the imagination at an arguably impressive rate of adoption, making the need for federal guidance an urgent one. ${ }^{16}$

Because the hologram is an emerging technology, there is a severe lack of precedent to look towards for guidance. However, a comparison to right of publicity and video games cases offers insight on the virtual incorporation of one's likeness and whether the First Amendment allows the use without license. ${ }^{17}$

11. McCarthy, supra note 9.

12. See Salomon, supra note 2 ("A federal statute could provide a solution to this all or nothing situation."); Krista Correa, Article: All Your Face Are Belong To Us: Protecting Celebrity Images in Hyper-Realistic Video Games, 34 Hastings Comm. \& ENT. L.J. 93, 122 (2011). ("The need for a federal right of publicity statute is increasingly clear, given the plethora of related lawsuits brought in the context of video games in recent years. The traditional tort laws may have been sufficient in the days of print media (though that statement itself is certainly open to debate) but they are no longer adequate today."); Shannon Flynn Smith, Comment, If It Looks Like Tupac, Walks Like Tupac, and Raps Like Tupac, It's Probably Tupac: Virtual Cloning and Postmortem Right-of-Publicity Implication, MicH. ST. L. REV. 1719, 1722 (2013) (recommending the "federalization of a right of publicity that would require an artist to contractually opt in before his or her postmortem virtual clone may be created."); Jonathan S. Jennings, Right of Publicity in Cyberspace, http://www.pattishall.com/pdf/Publicity-Cyberspace.pdf.

13. Tovin Lapan, Hollow-Grams or Holla-grams? New Technology Lets the Dead Perform Again, CuePoINT (May 8, 2015), https://medium.com/cuepoint/holographic-pop-the-art-ofresurrecting-the-dead-82180bb5bcf8\#.tha6tn21q.

14. See generally Smith, supra note 12, at 1720-30 (comparing biological cloning to virtual cloning).

15. Jenny Montgomery, 'Hologram' Performance by Tupac Creates Legal Questions for IP Lawyers, TheIndianaLAWYER.com (May 9, 2012).

16. LexInnova, Virtual Reality (2015) (summarizing industry trends and intellectual property landscape).

17. Elec. Arts, Inc. v. Davis, 775 F.3d 1172 (9th Cir. 2015) en banc, cert. denied Mar.2016. 
Right of publicity cases that involve video game publishers are multiplying and apply many tests for balancing the right to control one's own image against the First Amendment freedom of expression. ${ }^{18}$

Part II will explain "holograms" as they are being used in home entertainment and virtual reality, and how their use is rapidly changing the technological landscape. Part III will survey complicated issues in U.S. right of publicity laws among the states and address treatment through home entertainment and video game publishers. Part IV will explore tools used by France, Germany, and the European Union as a whole for protecting citizens' rights to control their own image. Part V recommends key concepts from the European perspectives to improve image control for U.S. citizens.

\section{HOLOGRAMS AND THE RIGHT OF PERSONALITY}

Holograms and other forms of digital technology that were once only a feature in science fiction films are now a reality. As of 2015, hologrammed humans are directing traffic in busy areas at some airports and helping travelers with directions. One need only approach and speak to the hologram to receive a response. ${ }^{19}$ These holograms may become a regular fixture in everyday life. ${ }^{20}$ Further, the possible uses of digital hologram technology are endless, including the potential to make a notable contribution to medical science. ${ }^{21}$ However, it is the entertainment industry that is currently capitalizing on the technology and implicating rights of publicity or personality issues. ${ }^{22}$

(petitioning for certiorari from SCOTUS, asking "Whether the First Amendment protects a speaker against a state-law right-of-publicity claim that challenges the realistic portrayal of a person in an expressive work.") [hereinafter EA v. Davis].

18. Hart v. Elec. Arts, Inc., 717 F.3d 141 (3d Cir. 2013); Thrower v. NCAA, No. C 09-1967 CW, 2012 U.S. Dist. LEXIS 70631 (N.D. Cal. May 21, 2012); No Doubt v. Activision Publg, Inc., 192 Cal. App. 4th 1018, 122 Cal. Rptr. 3d 397 (2011); Brown v. Elec.. Arts, Inc., No. 2:09-cv01598-FMC-RZx, 2009 U.S. Dist. LEXIS 131387 (C.D. Cal. Sept. 23, 2009); Kirby v. Sega of Am., Inc., 144 Cal. App. 4th 47, 50 Cal. Rptr. 3d 607 (2006).

19. Jana Moser, Tupac Lives! What Hologram Authors Should Know about Intellectual Property Law, Businesslawtoday (Sept.2,2012), http://www.americanbar.org /publications/blt/2012/08/02_moser.html (reporting the announcement of holograms places at three airports to assist in frequently asked questions).

20. Press Release Business Wire, Pulse Evolution and Japan's VTEC Laboratories Announce Joint Venture to Develop Immersive Entertainment Solutions for Virtual Reality Display, (Nov. 17, 2015), http://www.businesswire.com/news/home/20151117007008/en/Pulse-EvolutionJapan\%E2\%80\%99s-VTEC-Laboratories-Announce-Joint, (predicting digital holograms will be common).

21. Brian Handwerk, Medical Holograms are Now Part of a Surgeon's Toolkit, SMithSONIAN.COM (Mar. 27, 2015), http:/www.smithsonianmag.com/science-nature/medicalholograms-are-now-part-surgeons-toolkit-180954791/?no-ist.

22. Right of publicity and right of personality and image control will all be addressed and used interchangeably in certain points in this Note. 


\section{A. Raising the Dead by Hologram}

Notably, Tupac was resurrected on stage at the 2012 Coachella Valley Music and Arts Festival through advanced digital technology. ${ }^{23}$ The result was a surge of rumors and wishes about the next hologram performance. ${ }^{24}$ Later, in 2014, Michael Jackson posthumously performed on stage at the Billboard Music Awards. ${ }^{25}$ In 2016, Jackie Wilson, who inspired the likes of Elvis Presley and James Brown, was scheduled to be reincarnated in order to wow audiences on the strip in Las Vegas. ${ }^{26}$

The digitally projected performers have been dubbed "holograms," which is not an exact term for the apparitions. ${ }^{27}$ Actual holograms would appear in the air by light only and not as a reflection. ${ }^{28}$ The hologram digital creations are projected onto a transparent screen, which may be flat or concave. ${ }^{29}$ The concave screen used at Coachella in 2012 was touted to have a more realistic appearance of the performer on stage. ${ }^{30}$ Michael Jackson's performance at the Billboard awards gave a more cinematic feel. ${ }^{31}$ In either case, some critics felt a certain uneasiness or discomfort with the performances because it is well known that the performers are no longer alive. ${ }^{32}$

What is even more mystifying is that the digital creations are not projections

23. Westfesttv, Tupac Hologram Snoop Dogg and Dr. Dre Perform Coachella Live 2012, YouTuBE (Apr. 17, 2012), https://www.youtube.com/watch?v=TGbrFmPBV0Y.

24. See Lapan, supra note 13 (listing the other posthumous celebrity performances predating Tupac and the attention the Coachella performance received).

25. Bperkins400, Michael Jackson's Too Real Hologram Stuns Fans Watching BBMAS, HollywOod LIFE (May 19, 2014), http:/hollywoodlife.com/2014/05/19/michael-jacksonhologram-performance-stuns-fans-2014-billboard-music-awards/.

26. Robin Leach, Strip Scribbles: New Shows, Cabaret Club and Strip Star, Plus CES Security, Las Vegas Sun (Dec. 30, 2015), http://lasvegassun.com/vegasdeluxe/2015/dec/30/stripscribbles-new-shows-cabaret-club-star-ces-/.

27. Sam Biddle, Tupac Hologram Wasn't a Hologram, Gizmodo (Apr. 17, 2012), http:/gizmodo.com/5902625/tupac-hologram-wasnt-a-hologram.

28. See Lapan, supra note 13 ("While it has become commonto dub these digital performances "holograms," the term is a misnomer. Technically, a hologram is a $3 \mathrm{D}$ recreation of an object that is visible from every vantage point. In practice, however, the digital performers unveiled so far are two-dimensional, can only be viewed from certain perspectives and are created with several light projectors and angled screens using a centuries-old illusion technique called Pepper's Ghost.").

29. See Biddle, supra note 27.

30. Musion Eyeliner Foil-Holographic 3D Projection Screen, Dimensional Studios http://www.eyeliner3d.com/musion_eyeliner_advantages.html, (last visited Dec. 19, 2015 at12:00 am) [hereinafter Musion].

31. Id.

32. See Bperkins400, supra note 25 . 
of past performances. ${ }^{33}$ The holograms were digital puppets performing at the will of a programmer. For example, Tupac yelled to the audience in 2012, "What [. . .] is up, Coachella!?" 34 Yet the Coachella music festival had not been created until after Tupac's death. Therefore, Tupac never recorded his voice speaking the festival's name before death. ${ }^{35}$ Additionally, Tupac never performed the song "Hail Mary" live, thus it was not a replay of a past performance. ${ }^{36}$ Similarly, Michael Jackson performed, in hologram form, a song that was never released, let alone performed live. ${ }^{37}$ These productions of completely new performances resulted in some witnesses' adulating that the celebrities are still alive. ${ }^{38}$

Though Tupac was not the first digital reincarnation of celebrity performances, it was a breakthrough in digital representation. ${ }^{39}$ These types of holograms successfully passed a point for which the human brain will accept an image as something more than a digitally manufactured image. ${ }^{40}$ Masahiro Mori, a robotics professor at the Tokyo Institute of Technology, coined the term "uncanny valley" to describe a disturbing tug felt when animation approaches being realistic, but the brain identifies the mechanization. ${ }^{41}$ Mori's study identified that humans respond positively to artificial humans with greater affinity the more a robot appears to become human, up to a point. ${ }^{42}$ However, there is an area where humans find the representation disturbing. ${ }^{43}$ The "uncanny valley" is a steep drop on a graph plotted by Mori. ${ }^{44}$ The points on the graph are a measure for the study participants' acceptance of or affinity for the lifelike automata. ${ }^{45}$ The $\mathrm{x}$-axis values start with a low affinity to an obvious robot which become greater

33. See Smith, supra note 12, at 1720.

34. Jason Lipshutz, Opinion, The Problem with the Tupac Hologram, BILlBOARD (Apr. 16, 2012), http:/www.billboard.com/articles/columns/the-juice/494288/opinion-the-problem-with-thetupac-hologram.

35. See Smith, supra note 12 , at 1720.

36. Id.

37. See Bperkins400, supra note 25 .

38. Was Tupac at Coachella a Hologram or...?; Update: Tupac's Hologram Now has Twitter Account, TwITchy (Apr. 26, 2012), http://twitchy.com/2012/04/16/twitter-unsure-whethertupac-hologram-was-really-a-hologram/ (summaries of Twitter feeds).

39. See Lapan, supra note 13.

40. Id.

41. Id.

42. Masahiro Mori, The Uncanny Valley, 7 ENERgy 33 (1970) (republished in IEEE Robotics \& Automation Magazine (June 2012) (transl. with permission to English from Japanese by Karl F. MacDorman and Norri Kageki)) http://spectrum.iee.org/automaton/robotics/ humanoids/the-uncanny-valley.

43. Id.

44. Id.

45. Stephanie Lay, The Uncanny Valley: Why We Find Human-Like Dolls and Robots So Creepy, TheGuardian (Nov. 13, 2015), http://www.theguardian.com/commentisfree/2015/nov/ 13/robots-human-uncanny-valley. 
as the representation nears a real human. ${ }^{46}$ The y-value increases as the participant appreciates the human-like characteristics of a machine. ${ }^{47}$ Mori explained that one of the main objectives for robotics is to come as close to human as possible in order to bridge the valley with a positive human acceptance. ${ }^{48}$

The objective to cross the "uncanny valley" has been transferred to digital graphics in movie effects by CGI, video game makers, and, now, in digitally projected hologram performances. ${ }^{49}$ Digital animation technology has surpassed the "uncanny valley." ${ }^{50}$ For video game creators, this objective has yet to be met, but continues to improve. ${ }^{51}$ Consumers continue to seek the most realistic digitally manufactured experiences. ${ }^{52}$ There is still much debate over whether the performances of posthumous celebrities has reached the level in which the audience is absolutely fooled, and there are other relevant factors involved, such as the foundational knowledge that the performer is deceased.

\section{B. Taking Digital Humans Home}

The entrance into home entertainment, outside of the television screen, for this realistic digital hologram technology is underway. ${ }^{53}$ Currently, different companies are working with prototypes and displaying technology at tradeshows for home entertainment focused on creating as realistic a three-dimensional experience as possible. ${ }^{54}$ Microsoft created HoloLens, but has not released this product for purchase yet. ${ }^{55}$ Pulse Evolution and VTECH recently formed a joint venture to develop a personal Head Mounted Display (HMD) player, as well. ${ }^{56}$

HoloLens is a set of Virtual Augmentation (VA) goggles which digitally project three-dimensional holograms into the user's reality. ${ }^{57}$ The headset is only

46. Id.

47. Id.

48. Mori, supra note 42, at 33.

49. Guppmeister, 10 Games with the Best Video Games Graphics in 2015, GAMERs DeCIDE, http://www.gamersdecide.com/pc-game-news/10-games-best-video-game-graphics2015[https://perma.cc/KTJ3-WXDK] (last visited December 22, 2015 at 10:35 pm).

50. Lapan, supra note 13.

51. Correa, supra note 12, at 95.

52. Id.

53. MarketLinePulse Evolution forms joint venture with VTEC Laboratories, MARKETLINE (Nov. 17, 2015) http://advantage.marketline.com.proxy.ulib.uits.iu.edu/Product?pid=FD655532 [https://perma.cc/G7TE-B27S] [hereinafter MarketLine].

54. Jason Fonbuena, Microsoft Invites Developers for HoloLens Augmented Reality Headset Demos at NYC Store, Youth Health (Jan. 6, 2016), http://www.youthhealthmag.com/ articles/30492/20160106/microsoft-hololens-augmented-reality.htm [https://perma.cc/8KXFDY7Q]; BUSINESS WIRE, supra note 20; MarketLine, supra note 53.

55. Fonbuena, supra note 54.

56. MarketLine, supra note 53.

57. Michael Nuñez, Look Inside Microsoft's Secret HoloLens Room at Its Flagship Store in 
a couple of years away from coming to market. ${ }^{58}$ In the meantime, software developers are receiving exclusive invitations to try the technology at the Microsoft store in New York City. ${ }^{59}$ Microsoft also began a national consumer tour to raise awareness through demonstrations. ${ }^{60}$ Popular Science reported HoloLens currently only has three applications to sample. ${ }^{61}$ One application allows the user to create three-dimensional holograms much like graphic drawing software in which the user may access building tools. ${ }^{62}$ A second application demonstrates gaming possibilities. ${ }^{63}$ The third demonstrated storytelling whereby multiple users could wear a set of goggles and experience a story which interacts with each audience members' vision through eye tracking. ${ }^{64}$

Arguably, the most culpable of right of publicity violations is the joint venture between Pulse Evolution and VTECH. Pulse Evolution is the creator of the Michael Jackson hologram. Further, the venture is intended to create "immersive entertainment access for standard virtual reality (VR) systems" for users in their homes. ${ }^{65}$ Users will be able to experience "unique live events, such as virtual music concerts, multi-player games and other events set in rich VR environments." ${ }^{66}$ The programs will be "populated by hyper-realistic digital humans," thanks to Pulse Evolution. ${ }^{67}$

Although digital programming has made a significant leap over the "uncanny valley," these developments in home entertainment present an issue arguably more disturbing than only being plunged into "uncanny valley." The CEO of VTEC believes that the world will soon be overrun with digital humans, and since "Pulse is the gold standard of human animation," the venture positions the two companies on the forefront of writing this future history. ${ }^{68}$ With Pulse's ability to create realistic digital humans and VTECH's ability to create games for VR in home entertainment, video games will make personalities into digital puppets, which perform at the will of the players. Consider as well, the capacity to import human images into the hologram building application through HoloLens without limitation.

The imminent situation poses many questions: How should this ability to animate a realistic digital human on stage or in one's home be treated? Is it like

NYC, Popular Science (Dec. 17, 2015), http://www.popsci.com/look-inside-microsofts-secrethololens-room-flagship-store [https://perma.cc/FT5D-S5EG].

58. Id.

59. Id.

60. See Experience Microsoft HoloLens, Microsoft (2015), https://www.hololensevents. com[https://perma.cc/26HU-HZCC] (listing tour schedule).

61. Nuñez, supra note 57.

62. Id.

63. Id.

64. Id.

65. MarketLine, supra note 53.

66. BUSINESS WIRE, supra note 20.

67. Id.

68. Id. 
human trafficking, if the digital humans are sold, owned, and controlled by another person? Will companies like Pulse Evolution and Hologram USA be able to sell the digital humans to be controlled like first person video games? Will consent be required in an expressive work utilizing holograms? Currently, there is no adequate guidance in the U.S. on these complex questions, and each state provides different treatments of citizens' own image control.

If the purpose of the virtual video games is to either experience being the celebrity or being with the celebrity, and the game is sold commercially, the publisher should be required to attain a license or some written authorization regardless of how significant a role the celebrity plays. The following sections will explore rights of publicity in the event that a celebrity becomes a digital hologram in home entertainment sold around the world. U.S. courts recently addressed right of publicity claims against video games publishers without adequate consent, which are insightful for the purposes of the hypothetical future image takings in virtual reality. ${ }^{69}$

\section{THE RIGHT OF PERSONALITY IN THE U.S.}

There is no overarching right of personality for U.S. citizens; at least, it has not been explicitly stated by any Federal Act or Supreme Court decision. The Supreme Court of the United States (SCOTUS) touched on the right of publicity once on certiorari in which the Court simply acknowledged that a performer has an economic interest in a performance and that the First Amendment did not prevent a state from granting relief to a plaintiff when the news broadcasted the performance and diluted his economic interest. ${ }^{70}$ A great deal of scholarship covers a request for a federal right of publicity. ${ }^{71}$ However, not all states acknowledge a right of publicity, and when they do, these rights vary from state to state. Moreover, the balancing tests used in many courts pitting the right of publicity against freedom of expression are inconsistent. ${ }^{72}$ The U.S. is missing an

69. Hannes Rosler, Dignitarian Posthumous Personality Rights - An Analysis of U.S. and German Constitutional \& Tort Law, 26 Berkeley J. INT'L. L. 153, 159 (2008) (The European Union Court for Human Rights Convention decided many cases that influenced even English Law to create some privacy common law.).

70. Zacchini v. Scripps-Howard Broad. Co., 433 U.S. 562, 578 (1977).

71. See Alain J. Lapter, How the Other Half Lives (Revisited): Twenty Years Since Midler v. Ford: A Global Perspective on the Right of Personality, 15 TeX. InTELl. Prop. L. J. 239, 243 (2007); Susannah M. Rooney, Note, Just Another Brown-Eyed Girl: Toward a Limited Federal Right of Publicity Under the Lanham Act in a Digital Age of Celebrity Dominance, 86 S. CAL. L. REV. 921 (2013) (among others).

72. Reply Memorandum In Support Of Defendants' Motion To Dismiss The Amended Complaint And For Sanctions at 1, Lohan v. Take-Two Interactive Software, Inc., (No. 156443/2014), https://iapps.courts.state.ny.us/fbem/DocumentDisplayServlet?documentId= $1 \mathrm{mOLS4SJY10K0xZ1qrTJcg== \& system=prod} \mathrm{[https://perma.cc/6SA3-2QES];} \mathrm{see} \mathrm{also} \mathrm{Eriq}$ Garnder, Lindsay Lohan Bulks Up Lawsuit Over 'Grand Theft Auto' Character, THE Hollywood 
established law, or reliable foundation for one's right of personality that would allow relief in spite of creative expression when one monopolizes another's personality without consent.

Video games, which are becoming more realistic, are reasonable examples of potential treatment of personality rights regarding the evolving hologram home entertainment. A recent decision in the Ninth Circuit regarding the right of publicity in video games is helpful in describing the personality protection in a jurisdiction that statutorily recognizes the right of publicity. ${ }^{73}$ In Keller v. Elec. Arts Inc., the Court affirmed the lower court's finding that "[u]nder the 'transformative use' test developed by the California Supreme Court, Electronic Art's use does not qualify for First Amendment protection as a matter of law because it literally recreates Keller in the very setting in which he has achieved renown." 74

In a companion case, Electronic Arts (EA) petitioned SCOTUS on certiorari to answer the question of "[w]hether the First Amendment protects a speaker against a state-law right-of-publicity claim that challenges the realistic portrayal of a person in an expressive work," but the petition was denied. ${ }^{75}$ This denial could be because it is unnecessary to fix that which is not broken, and the Court let the ruling stand. If SCOTUS were to answer this question the way it was written, it would only provide insight for states that acknowledge a right of publicity.

Since a right of personality is broader than only the right of publicity, it arguably would be more insightful for this Note topic if SCOTUS would answer whether the First Amendment was intended to enable media platforms to monopolize a personality of a United States citizen. An injured citizen must persevere through many proceedings to reach the level of SCOTUS. ${ }^{76}$ It is unascertainable at this time to what degree or if SCOTUS will consider a right of personality. In any case, it is within the Court's power, and there is a foundation in privacy explained in the following section.

\section{A. Brief History on the Development of the Right of Publicity}

The right of publicity in the U.S. grew from the right of privacy, first

REPORTER (Oct. 9, 2014), http://www.hollywoodreporter.com/thr-esq/lindsay-lohan-bulks-uplawsuit-739538 [https://perma.cc/Q4FD-U8Y2].

73. Keller v. Elec. Arts Inc., 724 F.3d 1268, 1268 (9th Cir. 2016).

74. Id., at 1271 .

75. Petition for a Writ of Certiorari, Elec. Arts, Inc. v. Davis (Jan. 4, 2016, rescheduled) (Mar. 2016, cert. denied), Docket 15-434, http://www.scotusblog.com/wpcontent/uploads/2015/11/EA-v.-Davis-Cert-Petition-w-Appendix.pdf [https://perma.cc/DQG4P8W2].

76. See Jacob Gershwin, Court Tosses Linsey Lohan's Lawsuit against 'Grand Theft Auto V' Makers, Wall Street Journal (Sept. 1, 2016), http://blogs.wsj.com/law/2016/09/01/courttosses-lindsay-lohans-lawsuit-against-grand-theft-auto-v-makers/ [https://perma.cc/E6VA-CEH4] (explaining the loss of Lindsay Lohan against Rockstar Entertainment in the New York Courts). 
expressed by Brandeis and Warren in 1890 as the "right to be let alone." Thomas McCarthy named three major law review articles that shaped the development of the right of publicity, one by Brandeis and Warren, then Melville Nimmer in 1954, and William Prosser in $1960 .^{78}$

It was not until Halean Labs., v. Topps Chewing Gum, Inc., that the term right of publicity was understood as a separate economic interest in personality. ${ }^{79}$ Ignoring any possibility that a celebrity has a right to privacy "after the curtain falls," courts found it difficult to acknowledge a celebrity's right to be left alone until Halean ${ }^{80}$ Halean was brought by a plaintiff-baseball player about the use of his image on baseball cards to distribute gum. ${ }^{81}$ The court held that it did not matter that a right to control a man's photo and grant exclusive use of it was a property right because "the tag 'property' simply symbolizes the fact that the courts enforce a claim which has pecuniary worth." ${ }^{" 2}$ The Court then dubbed the interest "a right of publicity." 83

Halean was relevant to many celebrities who previously attempted a claim for embarrassment and injury to personal dignity, when they actually wanted to be compensated for the value of their image. ${ }^{84}$ Nimmer explained shortly thereafter that a celebrity should have a separate right of publicity because "although the well-known personality does not wish to hide his light under a bushel of privacy, neither does he wish to have his name, photograph, and likeness reproduced and publicized without his consent or without remuneration to him." ${ }^{" 85}$ After these developments to the right of publicity, a significant amount of litigation focused on advertising and consumer law, which will not be addressed here. ${ }^{86}$ Those issues do not adequately address the requirement of consent for holograms when incorporated in an expressive work. ${ }^{87}$

77. See Samuel D. Warren \& Louis D. Brandeis, The Right to Privacy, 4 HARV. L. REv. 193, 193 (1890); see also Michael Madow, Private Ownership of Public Image: Popular Culture and Publicity Rights, 81 CAL. L. REV. 125, 158 (1993) (after Brandeis and Warren, John Gilmer Speed, in 1896, wrote that even an actor has a right to privacy after "the curtain falls").

78. J. Thomas McCarthy, Melville B. Nimmer and the Right of Publicity: A Tribute, 34 UCLA L. REV. 1703, 1704 (1986-1987).

79. Halean Lab., v. Topps Chewing Gum, Inc., 202 F.2d 866, 868 (2d Cir. 1953).

80. Madow, supra note 77, at 172.

81. Halean Lab., 202 F.2d at 867.

82. Id. at 868 .

83. Id.

84. Madow, supra note 77, at 172-73.

85. McCarthy, supra note 78, at 1707.

86. Using the Name of Likeness of Another, Digital Media Law Project, http://www.dmlp.org/legal-guide/using-name-or-likeness-another [https://perma.cc/6HZG-MDP3].

87. See Restatement (Third) of Unfair Competition $§ 46$ (Am. Law Inst. (“One who appropriates the commercial value of a person's identity by using without consent the person's name, likeness, or other indicia of identity for purposes of trade is subject to liability for the relief appropriate under the rules stated in $\S \S 48$ and 49.”). 
The following paragraphs will specifically focus on the consent requirement to use a personality in an expressive work. The First Amendment is an affirmative defense to the collective right of personality complaints brought due to lack of consent. ${ }^{88}$ Copyright and First Amendment protections for transformative use bring a great deal of controversy about whether authorization or consent is necessary. ${ }^{89}$ For example, one artist created a painting which consists of a celebrity's image and subsequently sold the painting. ${ }^{90}$ The court held that the artist was excused from consent due to transformative use. ${ }^{91}$ However, in another case when a drawing of a celebrity was printed on a mug, the mug was considered merchandising the celebrity's image. ${ }^{92}$

\section{B. Personality Rights and Expressive Speech Litigation}

Courts deciding rights of publicity in cases involving simulation games using celebrities have utilized a variety of tests to balance the right of publicity against the freedom of speech defense..$^{93}$ If a digital celebrity hologram (as realistic as the Tupac or Michael Jackson holograms described in Part II) is inserted into a virtual reality game, where the player is performing on stage, the right of personality may take priority over the freedom of speech defense (at least in the Ninth Circuit). ${ }^{94}$ Unfortunately, there is no legal framework for rights of publicity when digital humans are taken home and animated like virtual puppets, because this is an area where technology has surpassed the speed of law; however, the following history of right of publicity claims against video game publishers may forecast future outcomes. It is, arguably, a leap between animation that is obviously digital and three-dimensional holograms that can fool the human brain, but the exploration is insightful.

Professor William Ford and Librarian Raizel Liebler expanded support for why video games should be treated as expressive works and not like merchandised "coffee mugs" that require licensing. ${ }^{95}$ Their article explains that

88. Anderson v. Fisher Broad. Cos., 712 P.2d 803, 810 (Or. 1986).

89. Jonathan S. Jennings, Right of Publicity Law Meets Social Media, AmERICAN BAR Association Annual MeEting: Social Media and the Potential Implications of the Right of Publicity and Other Intellectual Property Issues (Aug. 5, 2012) at 1 , https://www.pattishall.com/pdf/JSJ-ABA\%20Right\%20 of\%20 Publicity\%20 Law\% 20Meets\%20Social\%20Media.pdf [https://perma.cc/GF3A-YSWF].

90. ETW Corp. v. Jireh Publ'g, Inc., 99 F. Supp. 2d 829, 830 (N.D. Ohio 2000).

91. Id. at 834 .

92. C.B.C. Distrib. \& Mktg., Inc. v. Major League Baseball Advanced Media, 505 F.3d 818 (8th Cir. 2007). See also William K. Ford \& Raizel Liebler, Games Are Not Coffee Mugs: Games and the Right of Publicity, 29 SANTA Clara COMPuter. \& High TECH. L. J. 1, 14 (2012-2013).

93. Zacchini v. Scripps-Howard Broad. Co., 433 U.S. 562, 574-75 (1977).

94. Id.

95. Ford, supra note 92, at 4-6 (explaining the societal value of games as a whole and the difference between merchandizing and utilizing personalities in a creative work for expressive purposes). 
games in general and video games offer value to society and may be educational. ${ }^{96}$ The reference to fantasy baseball was particularly persuasive. ${ }^{97}$ Plaintiffs in C.B.C. Distribution and Marketing, Inc. v. Major League Baseball Advanced Media brought right of publicity claims for using the names and statistics of Major League Baseball players. ${ }^{98}$ The Eighth Circuit found that because the fantasy baseball game was a compilation of statistics, the image use was more akin to news (public media) than a game. ${ }^{99}$ Ford and Liebler argue that sports team simulation video games are similar because the game used statistics of the players to create the game. ${ }^{100}$

However, the authors did not consider the monopolization of another person's image when the manipulation of the character is less structured. A fantasy sports game player simply trades players in and out of his team. ${ }^{101}$ Sport video games involve much more than trading player statistics. Putting an image with words is much more powerful than the words alone. ${ }^{102}$ This can be recognized through the expansion of user platforms like Instagram, YouTube, and Pinterest. ${ }^{103}$ This comparison is given further relevance, considering the increased right of publicity concerns during the expansion of media sharing platforms, where the ability to publish and share images grows without limitation. ${ }^{104}$

Instead of addressing further invasions of publicity rights, the authors used the fact that video games are more involved than fantasy baseball as a platform for why they should be viewed as creative expressions. ${ }^{105}$ SCOTUS agreed, holding that video games are expressive works that deserve First Amendment protection; therefore, a right of publicity challenge against a video game publisher must pass any number of balancing tests that the court finds appropriate. ${ }^{106}$

\section{Id.}

97. Ford, supra note 92, at 36-39; see also C.B.C. Distrib. \& Mktg., Inc., supra note 92, at 820.

98. C.B.C. Distrib. \& Mktg., Inc, supra note 92.

99. Ford, supra note 92, at 36-39.

100. Id.

101. How Fantasy Football Works, ENTERTAINMENT, http://entertainment. howstuffworks.com/fantasy-football.htm (last visited Jan. 17, 2016 at 4:06 pm)(author uses the word "virtual" in the description, this should not be confused to any comparison in this Note regarding Virtual Reality (VR), as they are not related.).

102. Paolo Gaudino, As It Turns Out a Picture is Not Worth a Thousand Words, WiRED, http:/www.wired.com/insights/2014/03/turns-picture-worth-thousand-words/ (providing a comparison that images and words are not interchangeable, and media sharing has revolutionized the way we consume information).

103. Lynne M. J. Boisineau, Intellectual Property Law: The Right of Publicity and the Social Media Revolution, 30 GP Solo (2013).

104. Id.

105. Ford, supra note 92, at 36-39.

106. Brown v. Entm't Merchs. Ass'n, 131 S. Ct. 2729, 2733, (2011) ("[V]ideo games qualify for First Amendment protection. The Free Speech Clause exists principally to protect discourse on 
As briefly mentioned above, SCOTUS denied a petition for writ of certiorari from the Ninth Circuit regarding the question of a state right of publicity's ability to overcome the First Amendment in an expressive work by EA, in Electronic Arts v. Davis. ${ }^{107}$ The Ninth Circuit created protection for personalities implanted in role playing games based on how closely the digital personality was acting to what the person is known for doing, i.e. a musical artist performing in a rock band or an athlete playing college basketball in a basketball stadium. ${ }^{108}$

In an opposite outcome in New York, Lindsay Lohan complained against the makers of 'Grand Theft Auto V' for using her likeness. ${ }^{109}$ The trial court refused to dismiss Lohan's claims, but the appellate court disagreed, finding:

Even if we accept plaintiffs' contentions that the video game depictions are close enough to be considered representations of the respective plaintiffs, plaintiffs' claims should be dismissed because this video game does not fall under the statutory definitions of "advertising" or "trade."... This video game's unique story, characters, dialogue, and environment, combined with the player's ability to choose how to proceed in the game, render it a work of fiction and satire. ${ }^{110}$

Many were optimistic that SCOTUS would take the Davis case to settle "[w]hether the First Amendment protects a speaker against a state-law right-ofpublicity claim that challenges the realistic portrayal of a person in an expressive work." ${ }^{111}$ However, SCOTUS has denied many petitions for writ of certiorari

public matters, but we have long recognized that it is difficult to distinguish politics from entertainment, and dangerous to try. "Everyone is familiar with instances of propaganda through fiction. What is one man's amusement, teaches another's doctrine."); see also Winters v. New York, 333 U.S. 507, 510, (1948) ("Like the protected books, plays, and movies that preceded them, video games communicate ideas--and even social messages--through many familiar literary devices (such as characters, dialogue, plot, and music) and through features distinctive to the medium (such as the player's interaction with the virtual world). That suffices to confer First Amendment protection.").

107. DocKet SCOTUS BlOG, http://www.scotusblog.com/case-files/cases/electronic-arts-vdavis/ (last visited Jan. 10, 2016).

108. No Doubt v. Activision Publ'ns, Inc., 122 Cal. Rptr. 3d 397, 411 (2011).

109. See contra Jacob Gershwin, Court Tosses Lindsey Lohan's Lawsuit against 'Grand Theft Auto $V$ ' Makers, WALl Street Journal (Sept. 1, 2016), http://blogs.wsj.com/law/2016/ 09/01/court-tosses-lindsay-lohans-lawsuit-against-grand-theft-auto-v-makers/ (explaining the loss of Lindsay Lohan against Rockstar Entertainment in the New York Courts).

110. Id.

111. See Eugene Volokh, The First Amendment, The Right of Publicity, Video Games and the Supreme Court, WASHINGTON PosT (Jan. 4, 2016), https://www.washingtonpost.com/news/volokhconspiracy/wp/2016/01/04/the-first-amendment-the-right-of-publicity-video-games-and-thesupreme-court/; See also SCOTUS BLOG DoCKET, http://www.scotusblog.com/casefiles/cases/electronic-arts-v-davis/ (last visited Jan. 10, 2016) (listing multiple amicus briefs exhibiting the extent to which interest groups have gone to persuade the Court to make a decision); see also Petition for a Writ of Certiorari to the United States Court of Appeals for the Ninth Circuit 
from similar cases. ${ }^{112}$ The multiplicity of litigation between athletes and performers against video game makers created significant uncertainty for video game publishers.

Another criticized suggestion for balancing the right of publicity in creative works is differentiating between higher and lower artistic expressions, fine art versus caricature, and placing respective weight on freedom of expression. ${ }^{113}$ One Amicus Brief for Davis argued that it "necessarily creates uncertainty for lower courts and for speakers." The group discussed the different treatments of higher and lower art as already problematic:

The Sixth Circuit in ETW, the Eighth Circuit in C.B.C., and the California Supreme Court in Winter treated prints, fantasy baseball games, and comic books as fully protected by the First Amendment. The Ninth Circuit in Hilton, the Third and Ninth Circuits in Hart, Keller, and this case, and the Missouri Supreme Court in Doe apparently treated cards, video games, and comic books as less constitutionally protected. (Of course, if those latter cases treated those media as fully protected, that would be even worse; as noted above, that would jeopardize traditional books and films.) Such uncertainty is inevitable unless this Court steps in to resolve it. ${ }^{114}$

Some argue the Lanham Act is sufficient to identify when the right of publicity should be protected. ${ }^{115}$ However, such a claim was unsuccessful for James Brown, a historically recognized football player for the Cleveland Browns, when he was denied relief against EA for the "unauthorized use of [the] retired sports celebrity's likeness." 116 Brown argued that EA violated the Lanham Act which is designed to protect consumers from false endorsements. ${ }^{117}$ Eventually, EA's motions to dismiss were successful. ${ }^{118}$ The Court found, "even if EA used Brown's likeness in its video games, such use was protected under the First Amendment due to the game being an expressive work." 119 The Ninth Circuit affirmed the lower court's dismissal because Brown did not satisfy the Rogers test for the Lanham Act. ${ }^{120}$ The Rogers test for the Lanham Act in right of

presenting the question.

112. Elec. Arts Inc. v. Keller, 135 S. Ct. 42 (2014), cert. dismissed; Factors Etc., Inc. v. Memphis Dev. Found., 449 U.S. 953 (1980), cert. denied.

113. Brief of 31 Constitutional Law and Intellectual Property Law Professors as Amici Curiae in Support of Petitioner at 21, SCOTUS BLOG DocKeT, http://www.scotusblog.com/wpcontent/uploads/2015/11/15-424-Amici-Brief.pdf (last visited Feb. 2, 2016).

114. Id. at 22 .

115. See Rooney, supra note 71, at 921-22.

116. Brown v. Elec. Arts, Inc., 722 F. Supp. 2d 1148, 1148 (C.D. Cal. 2010).

117. Id.

118. Id.

119. Id. at 1151.

120. Brown v. Elec. Arts, Inc., 724 F.3d 1235 (9th Cir. 2013). 
publicity claims is a question of whether the use would lead a reasonable person to believe that the personality endorsed the product. ${ }^{121}$

The varied treatment of right of personality against freedom of expression in the U.S. is inconsistent; and neither provides adequate protection for the personalities, nor notice for expressive authors attempting to incorporate a personality in expressive works. Since digital media is shared and sold around the world, it is practical to look to another system in which, perhaps, the right of personality is a human right.

\section{EUROPEAN PERSONALITY RIGHTS AND CONSENT}

The European Convention on Human Rights, Germany, and France have a strong foundation in the right of personality, which also includes an acknowledgement of an economic interest in personality, like the U.S. right of publicity. ${ }^{122}$ These three jurisdictions and their respective bodies of law considered similar struggles to the U.S. in finding both moral and economic interests in personality. ${ }^{123}$ No matter where publicity or personality rights evolved, one common melee courts experienced was between moral or economic rights. ${ }^{124}$ Economic interests are often satisfied more easily for the U.S. due to the necessary measurability of an injury. ${ }^{125}$ In addition, celebrity culture is viewed as more American; and such an economic interest was not acknowledged until much later in Europe. ${ }^{126}$

Since the potential violation for digital holograms is arguably of a more intimate nature due to the exactness of the replication of a person, the moral or dignity interest and the economic interest should be considered together. As such, the perceptions of the European Union collectively, and of the countries of Germany and France individually are insightful. The European Convention on Human Rights (ECHR) acts as a European "Bill of Rights."127

121. Kevin L. Vick \& Jean-Paul Jassy, Why a Federal right of Publicity Statute is Necessary, 28 COMMUNICATIONS LAWYER 14, 15 (Aug. 2011), http://www.americanbar.org/content/dam/aba/ publications/communications_lawyer/august2011/why_federal_right_publicity_statute_is_neces sary_comm_law_28_2.authcheckdam.pdf.

122. See Giorgio Resta, Article, The New Frontiers of Personality Rights and the Problem of Commodification: European and Comparative Perspectives, 26 TUL. EUR. \& CIV L.F. 33, 49 (2011) (explaining that the U.S. began with privacy first and later a separate full economic property right leaving a gap; whereas European countries began with a functional evolution of personality rights; "statutory provisions on name, likeness, and other personal indicia have never impeded an instrumental use of personal remedies to advance purely an economic interest." (citations omitted)).

123. Id.

124. Id.

125. See generally Saul Litvinoff, Moral Damages, 38 LA. L. ReV. (1977), http://digitalcommons.law.lsu.edu/lalrev/vol38/iss1/4.

126. Resta, supra note 122 , at 48-51.

127. BRÜGGEMEIER, supra note 6 , at 30 . 


\section{A. The European Convention on Human Rights}

Right of publicity protection has not been specifically addressed by any international treaties; however, the European Court on Human Rights (ECtHR) upholds the European Convention on Human Rights (ECHR) created by the Council of Europe, and has addressed many cases where a European country either did or did not recognize a right to control the plaintiff's image. ${ }^{128}$ The Council of Europe is an "international organization which aims to promote democracy, the rule of law, human rights," created after World War II, and is not to be confused with the European Union (EU). ${ }^{129}$

It is against the ECHR to indefinitely hold one set of rights as more important than another. ${ }^{130}$ Both dignity and freedom of speech are considered in the context of each case and which right violation is more injurious. ${ }^{131}$ Some critics argue that dignity is used in many legal frameworks that may be inappropriate; because when reason becomes difficult, it can be reasoned on behalf of dignity. ${ }^{132}$ Regardless of whether dignity is well defined, it served as a foundation for a civil society which balances all rights so that one does not take or deny another of what is so ingrained in the meaning of being human. ${ }^{133}$

One case in particular, brought by Princess Caroline von Hannover, provides an example of the difficulty in balancing the rights set forth in the ECHR. Princess Caroline heavily litigated her personality right of privacy when she felt violated by the media. Princess Caroline was the first child born to Prince Rainier III of Monaco and Grace Kelly. ${ }^{134}$ Grace Kelly was a wildly coveted stage and

128. Lapter, supra note 71, at 306; Press Unit, Factsheet-Right to the Protection of One's Image, European Court of Human Rights (June 2016), http://www.echr.coe.int/Documents/ FS_Own_image_ENG.pdf [hereinafter Factsheet].

129. Sarah Daizell, Spot the Difference: The European Union or European Convention on Human Rights?, RightsINFO.ORG, https://rightsinfo.org/whats-difference-european-unioneuropean-convention-human-rights/ (June 21, 2016) (last visited March 20, 2017); see also Resta, supra note 122, at 37-38 (expanding on the laws and private right of action in the EU, an area too expansive for this Note) ("Recent codes and reform projects confirm the importance of tort law as one of the most important frontiers for the recognition and safeguard of personality interests in private law. In particular, concerns for the extra-contractual protection of human dignity, one of the founding values of post-war constitutionalism, have risen to prominence and tend to occupy the center of the stage. Not surprisingly, the drafters of the European Principles on Non-Contractual Liability (now Book VI of the Draft Common Frame of Reference) have devoted a specific article to privacy and dignity, transposing into private law a precept solemnly proclaimed by art. 1 of the European Charter of Fundamental Rights).

130. BARNES, supra note 1 , at 15.

131. Id.

132. See generally Christopher McCrudden, Human Dignity and Judicial Interpretation of Human Rights, 19 Eur. J. INT'L L. 655, 656-63 (2008).

133. Id.

134. BARNES, supra note 1, at 1 (2010). 
film actress enjoying a successful career for years prior to meeting the Prince. ${ }^{135}$ When the two married, the couple was sensationalized and as their child, Princess Caroline became a publicity target. ${ }^{136}$ Caroline was featured in tabloid magazines, where photographs of her from many ordinary activities were published as news, including outings with her own children. ${ }^{137}$ Many photographs were taken in France, then sold to be published in Germany. ${ }^{138}$ She was stalked by the press whenever she left the house. ${ }^{139}$

In an attempt to fight back, Princess Caroline sought an injunction in German Courts against Burda Publishing. ${ }^{140}$ She claimed that she had a "right to protect her personality, access to her private life, and use and control of her image."141 The German Court denied her request to enjoin the defendant from publishing her photos, finding the defendant's argument more persuasive. The publisher claimed that Caroline was "a figure of contemporary society, and as such, her rights to protection of private life stopped at her front door." 142

Subsequently, the Princess filed her complaint in the ECtHR against Germany, this time, for denying her rights. ${ }^{143}$ This resulted in a landmark decision in the Princess' favor. ${ }^{144}$ The ECtHR explained the right to control one's own image as:

[A] person's image constitutes one of the chief attributes of his or her personality, as it reveals the person's unique characteristics and distinguishes the person from his or her peers. The right to the protection of one's image is thus one of the essential components of personal development. It mainly presupposes the individual's right to control the use of that image, including the right to refuse publication thereof... ${ }^{145}$

Though the Court acknowledged that publishing photos is a freedom of expression, it is "an area in which the protection of the rights and reputation of others takes on particular importance, as the photos may contain very personal or even intimate information about an individual or his or her family."

Caroline von Hannover's was a complex case considering competing rights. Article 8 of the European Rights Convention enumerates the right to be left alone;

135. Grace Kelly Biography, BIOGRAPHY.COM, http://www.biography.com/people/gracekelly-9362226 (last updated July 8, 2014).

136. Barbara McDonald, Privacy Princesses and Paparazzi, 50 N.Y. L. REV 205, 217 (2006).

137. BARNES, supra note 1, at 3-5.

138. Id.

139. Id.

140. Id., at 5-6.

141. Id. at 6 .

142. Id., at 6 (emphasis in original).

143. McDonald, supra note 136, at 207-08.

144. von Hannover v. Germany (no. 2), Grand Chamber judgment of 7 February 2012.

145. Id. at $\S 96$.

146. Id. at $\S 103$. 
while Article 10 protects freedom of expression. ${ }^{147}$ As mentioned above, it is against the ECHR to indefinitely hold one set of rights as more important than another; therefore, the ECtHR must balance these rights. ${ }^{148}$ Princess Caroline's final victory in her plight against the media provides a perspective on privacy from a public figure which would have failed against the First Amendment in a U.S. court.

\section{B. Germany's Personality Rights}

The exploration of German law regarding personality rights and comparisons to U.S. law are relevant for many reasons. Both Germany and the U.S. balance freedom of speech against right of publicity. ${ }^{149}$ Additionally, each of their respective constitutions have acted as models for other developing countries. ${ }^{150}$ Further, both SCOTUS and the German Federal Constitutional Court hear cases on constitutionally provided rights. ${ }^{151}$ Likewise, both courts place a significant amount of weight on freedom of speech. ${ }^{152}$

The right of personality is implied from the German Constitution, the German Civil Code, and the German Act on the Protection of Copyright in Works of Art and Photographs of $1907 .{ }^{153}$ The right was first developed through case law, and it grants protection of "dignity and the free development of privacy." ${ }^{154}$ It is argued that Germany has the most unified approach to image rights. ${ }^{155}$

There are both commercial and non-commercial components to the right of personality. ${ }^{156}$ The commercial part of the right of personality that is most comparable to the American right of publicity is officially provided for under copyright as an interest in deciding to publish one's own image. ${ }^{157}$ The commercial component is an "economic issue of overarching personality rights." 158

The German overarching right of personality grants both interests regardless of celebrity status, whereas the U.S. does not provide the non-commercial

147. Id. at 208 .

148. BARNES, supra note 1 , at 6 .

149. Rosler, supra note 69 , at 163.

150. Id. at 160 .

151. Id.

152. Id.

153. Marcus von Welser, Right of Publicity: Germany, in Getting the Deal Through 49 (2014).

154. Id.

155. Tatiana Synodinou, Image Right and Copyright Law in Europe: Divergences and Convergences, LAws 182, 185 (2014), http://www.mdpi.com/2075-471X/3/2/181 [https://perma.cc/4EUQ-H32Q].

156. Welser, supra note 153 , at 49.

157. Synodinou, supra note 155 , at 184-85.

158. Rosler, supra note 69 , at 162. 
privacy-based interests for celebrities. ${ }^{159}$ Celebrities have no expectation of privacy past their front door in the U.S., because they are viewed as public figures and of a public interest. ${ }^{160}$ Also, it is difficult to place a monetary value on personality rights in general, which has made it a challenge for U.S. courts to provide adequate remedies for violation of those rights. ${ }^{161}$ However, personality rights in Germany are founded on dignity, and the rights are viewed as being significant to society. ${ }^{162}$ The idea that a person forfeits a human right of dignity when he or she becomes a celebrity is one indication that U.S. law has misconstrued personality rights. ${ }^{163}$

\section{Mephisto: Expressive Work Violated a Deceased Actor's Right of Personality}

One landmark case in the Federal Constitutional Court, commonly referred to as Mephisto, illustrates that "the notion of human dignity is the conceptual and normative backbone of all German constitutional law." 164 In Mephisto, the defendant publisher asked for a review of an interlocutor injunction granted against printing, distributing, and publishing the novel, Mephisto-Novel of a Career. ${ }^{165}$ One of the characters in the book was modeled after Klaus Mann's exbrother-in-law, Gustaf Gründgens. ${ }^{166}$ Mephisto is an outcome that could not occur in the U.S., since the affirmative First Amendment, freedom of expression, defense is difficult to overcome, whereas dignity is the right most elevated in Germany. ${ }^{167}$

The character modeled after Gründgens was similar to Gründgens in many ways besides his name. ${ }^{168}$ The character went by Hendrik Höfgen and likewise was an actor during the $1920 \mathrm{~s} .{ }^{169}$ Similarities included "physical appearance, the plays he acted in, and his appointments as State Councillor and Director-General of the State Theatre in Prussia." ${ }^{170}$ Mann even stated that he chose Gründgens as

159. See generally BARNES, supra note 1, at 7-9.

160. Id.

161. Rosler, supra note 69 , at 162.

162. Id.

163. Id.

164. Id. at 168 .

165. Id. at $154-55$.

166. Id. at 175 .

167. Brown v. Entm't Merchants Ass'n, 564 U.S. 786, 790, (2011) (“The Free Speech Clause exists principally to protect discourse on public matters, but we have long recognized that it is difficult to distinguish politics from entertainment, and dangerous to try."); McCrudden, supra note 132 , at 699.

168. Mephisto Case, BVerfGE 30, 173, Federal Constitutional Court, Feb. 24, 1971, German Law Archive (trans. Tony Weir, Trinity College, Cambridge), http://germanlawarchive.iuscommp.org/?p=56.

169. Id.

170. Id. 
a model for Höfgen because he was the "embodiment of corruption and cynicism," and the novel was a reflection of societal corruption in Nazi Germany. ${ }^{171}$ However, Höfgen's persona was more extreme, thus the novel was meant to be a satire of Gründgens' type. ${ }^{172}$ Gründgens' sole heir, an adopted son, felt that the negative portrayal was a revenge act based on hurt feelings from Gründgens' short marriage to Mann's sister. ${ }^{173}$

Notably, neither Gründgens nor Mann participated in the case because both were deceased. Mann wrote the satirical novel in Amsterdam, where he moved in the 1930s, and it was published. ${ }^{174}$ Mann died in 1942, and the novel was published in East Germany in 1949. ${ }^{175}$ Then, Gründgens died in $1963 .{ }^{176}$ In the same year, the publisher announced that the novel would be released in West Germany, inciting the lawsuit. ${ }^{177}$

The Court balanced the right to artistic freedom and freedom of expression against human personality rights, all granted by the German Constitution. The lower court granted the injunction to prevent the publisher from releasing the novel in West Germany, but not in East Germany, and the higher court was unable to come to a consensus. ${ }^{178}$ Finally, in 1968 the Federal Supreme Court, Germany's highest private court upheld the injunction. ${ }^{179}$ The court reasoned that the premise of the freedom of art is dignity; and dignity is the "supreme and controlling value of the whole system of basic rights." 180 Therefore, a derivative right of art would not overcome the overarching right to dignity for Gründgens. ${ }^{181}$ Furthermore, a person's "claim to social respect and value is not superior to artistic freedom, but neither can art simply ignore the individual's claim to proper respect." 182 Mephisto emphasized that the freedom of expression is not the one ultimate right that should be held above all others. ${ }^{183}$

171. Id.

172. Id.

173. Mephisto Case, BVerfGE 30, 173, Federal Constitutional Court, Feb. 24, 1971, German Law Archive (trans. Tony Weir, Trinity College, Cambridge), http://germanlawarchive. iuscommp.org/?p=56.

174. Id.

175. German Reunification, NEW WorLd ENCYCLOPEDIA, $\mathrm{http} / / /$ web.newworldencyclopedia.org/entry/German_reunification (last visited January 1, 2016) (Germany was split into East and West after WWII. The country was reunited in 1990.) [https://perma.cc/DQL8-U9RP].

176. Rosler, supra note 69 , at 176 (detailing more intimate details to this case like the fact that Klaus Mann committed suicide).

177. Mephisto Case, supra note 168.

178. Rosler, supra note 69, at 176.

179. Id., at 177 .

180. Mephisto Case, supra note 168.

181. Id.

182. Id.

183. Rosler, supra note 69 , at 178-79. 
Mephisto is insightful for the treatment of satire of a personality which had a very different treatment than in the U.S., explained in Part III, Section B with Lindsay Lohan in New York; however, Mephisto does not explain whether a celebrity image may be used in hologram projection entertainment without the consent of the celebrity if the representation was not made in bad taste. Compared to Mephisto, the representation may require a level of degradation of character to overcome artistic expression.

The reproduction of a digital human which surpasses the "uncanny valley" likely will be viewed as an ultimate use, a monopolization, of personality. A more modern decision may be a better comparison for analysis, because a personality's digital likeness was used in a video game without consent and the personality won. ${ }^{184}$

\section{FIFA Goalkeeper Personality Rights in Video Game}

Oliver Kahn, a well-known German goalie, brought charges in a Hamburg court against EA for using his name and likeness in a FIFA video game. ${ }^{185}$ According to one legal professional practicing in London, the case hinged on Kahn's character being "monopolized by its use as a player in a computer game;" and the monopolization of his image was enough justification to prevent EA from using his name and likeness. ${ }^{186}$ Besides the digital image, the court held that "the use of Kahn's name in the computer game damaged his general personality right in that it damaged his right to choose how his name might be used." 187

If the monopolization of a celebrity's image is enough to overcome artistic expression and require consent, then any production of a lifelike digital reproduction must require consent. Another legal professional practicing in Germany stated that the court considered the video game publisher's use of Kahn's likeness to be of a commercial nature. ${ }^{188}$ It is unclear whether video games can be considered artistic expressions, as the court in Kahn's case either rejected the video game publisher's arguments for expression of art or placed little value on the art. This is notable, because SCOTUS determined that a video game is an expressive work, which complicates the balancing of these rights in the U.S. ${ }^{189}$

184. Id.

185. James Hennigan, Altered Image Rights, ENT. L.R. 2003, 14(7), 161, 161 (2016) (unpublished) (James Hennigan is a Partner at Squire Patton Boggs in London for sports and entertainment law.).

186. Id.

187. Id. at 162 .

188. Jonas Rechtsanwaltsgesellschaft, Germany's Approach to Publicity Rights, WorLD TRADEMARK REviEw 72, 73 (2008), http:/www.worldtrademarkreview.com/Magazine/Issue/ 15/Country-correspondents/Germany-Jonas-Rechtsanwaltsgesellschaft-mbH (last visited Jan. 5, 2017) [https://perma.cc/2J4M-HTTR].

189. Brown v. Entm't Merchs. Ass'n, 131 S. Ct. 2729, 2733 (2011) ("Like the protected books, plays, and movies that preceded them, video games communicate ideas--and even social 


\section{Le Droit a L'Image of France}

Personality rights in France are "generally thought to consist of the moral rights of authors: the right to privacy, the right to protect one's honor and reputation, and the right to control the use of one's image." ${ }^{190}$ Controlling the use of one's image is to prevent the fixation and reproduction of one's likeness, voice, photograph, portrait, or video reproduction of the individual. ${ }^{191}$ The right belongs to any person regardless of celebrity status. ${ }^{192}$ It is commonly referred to as the French droit a l'image or "the right of image." 193

The courts derived the ability to administer damages for both moral and economic damages from Article 1382 of the Civil Code if one's image is used without consent. ${ }^{194}$ In 1970, Article 9 was incorporated, which "provides that '[e]veryone is entitled to respect of private life' and this article empowers the courts to issue drastic preliminary injunctions to prevent or stop intrusions into the intimacy of one's private life." 195 Accordingly, protection is administered by the requirement that "consent must be clearly expressed for both the taking and the using of a person's image." ${ }^{196}$ Foremost in applying French image to digital holograms is that the medium used to reproduce a person's image is immaterial to the misappropriation. ${ }^{197}$

\section{The Rachel Affair}

The famous Rachel case is significant, because it is considered the beginning

messages--through many familiar literary devices (such as characters, dialogue, plot, and music) and through features distinctive to the medium (such as the player's interaction with the virtual world). That suffices to confer First Amendment protection.").

190. Elisabeth Logeais \& Jean-Baptiste Schroeder, The French Right of Image: An Ambiguous Concept Protecting the Human Persona, 18 LoY. L.A. ENT. L. REV. 511, 519 (1998).

191. Lapter, supra note 71, at 286.

192. Id.

193. Logeais, supra note 190 , at 512.

194. Art 1382 C.civ (“Tout fait quelconque de l'homme, qui cause à autrui un dommage, oblige celui par la faute duquel il est arrive, à le réparer," summarily meaning that a person who damages another is liable for monetary damages); see also, Logeais, supra note 190, at 519 (explaining the courts' common law in which the damage may be in exploiting an image without consent).

195. Logeais, supra note 190, at 513.

196. Logeais, supra note 190 , at 519.

197. Lapter, supra note 71, at 287; see also, Logeais, supra note 190, at 519 n.39-40 ("CA Versailles, Mar. 8, 1996, Gaz. Pal. 1996, 213, Concl. Duplat, Attorney General [Philippe Le Gallou v. Fodè Sylla, Jeu National Multimedia and the Front National] (discussing a right-wing extremist political party that had conceived of a video game of dubious taste starring a caricature of Fode Sylla.)"). 
of image rights in France. ${ }^{198}$ Rachel was a famous actress of the nineteenth century who was photographed on her deathbed. ${ }^{199}$ Subsequent sketches made from the photos were sold commercially. ${ }^{200}$ Similar to Mephisto in Germany, Rachel acknowledged the dignity of the family and that the moral right of image or personality is passed to the heirs or next family; thus the court found that damages were appropriate to award to the family posthumously.

Since the Rachel Affair, the development of image rights in France is similar to that of the U.S. with a foundation in privacy. ${ }^{201}$ Personality rights developed "within a continuum leading from the alienable commercial copyright through to the inalienable." ${ }^{202}$ France also acknowledges a "general difficulty in placing a specific value on one's personal rights" and the inalienability of a personal attribute. ${ }^{203}$ However, the marketability of an intangible asset in a personality can neither be denied. ${ }^{204}$

\section{The Defamation of Scarlett Johansson}

France demonstrated a limitation and clarification of image rights in a recent case in which Scarlett Johansson filed a complaint against French author, Grégoire Delacourt for fraudulently exploiting "her name, her image, and her celebrity;" as well as defamation of character for false claims. ${ }^{205}$ Johansson's image was recreated through words by a French author in a fictitious novel about a model whose troublesome condition is that she is seen as a sex object. ${ }^{206}$ The model in the book is mistaken for Johansson as part of the storyline. ${ }^{207}$ The character in the book had two affairs in which the real Johansson never

198. See BrÜGgemeIER, supra note 6, at 11-12, n.20-23, (translating Trib. civ. Seine, 16 Jun. 1858, Rachel, D. 1858, 3, 62 ("“no one may, without the express consent of the family, reproduce and make the features of a person on his deathbed available to the public, however famous this person has been and however public his acts during his life. The right to oppose this reproduction is absolute; it flows from respect for the family's pain and it should not be disregarded; otherwise the most intimate and respectable feelings would be offended.'”); and Trib. civ. Seine, 15 Feb. 1882, D. 1884, 2, 22 Labbé; cf. Maillard, (“'Du droit au nom patronymique' (1894) Ann. prop. ind. 345. 202122 ")).

199. BRÜGGEMEIER, supra note 6 , at 11-12.

200. Id.

201. Logeais, supra note 190, at 511 n.6; Lapter, supra note 71, at 285.

202. BRÜGGEMEIER, supra note 6 , at 13 .

203. Lapter, supra note 70 , at 286.

204. Id.

205. Kim Willsher, Scarlett Johansson Wins Defamation Case Against French Novelist, THEGUARDIAN.COM (JuLY 4, 2014), https://www.theguardian.com/film/2014/jul/04/scarlettjohansson-wins-french-defamation-case [https://perma.cc/K42E-NTB4] (quoting complaint (omitting inside quotes)).

206. Id.

207. Id. 
participated. ${ }^{208}$

The author of the book, The First Thing You See, has a reputation for successful novels. ${ }^{209}$ Delacourt's last novel was published and translated into forty-seven languages. ${ }^{210}$ The heroine in the novel in question is tortured by her prison of Johansson's face and body, because men cannot see past the first thing they see. ${ }^{211}$ The model is denied an identity of her own. ${ }^{212}$ The author professed that this is a tribute to the actress and her beauty. ${ }^{213}$

The French Court granted her damages for the defamatory intrusion to her private image, but not any of her other image claims. ${ }^{214}$ The exploitation of name, image, and celebrity were dismissed. ${ }^{215}$ This is unusual, as it goes against the generally accepted requirement of consent. ${ }^{216}$ If Johansson brought similar claims in Germany or the U.S., it is unlikely that she would succeed on any of them either. ${ }^{217}$

Contrarily, the outcome may change if the story were transferred to a visual representation without Johansson's consent. Johansson has legitimate concerns that the novel about her doppelganger be considered for film production. ${ }^{218}$ Ideally for Delacourt, the actress would see the dedication of love for her and agree to play herself in such a production. ${ }^{219}$ Yet, Johansson did not view the expressive work as a tribute to her nor did it lead to a showing of gratitude in helping his creation come to life. ${ }^{220}$ Johansson viewed this as an intrusion to her right of publicity and an exploitation of her personality, which would sell books evoking her image.

Consider instead if a company like Pulse Evolution created Scarlett Johansson to portray the model in a play based on the novel. Many French image control principles created an unequivocal requirement for consent to create the image of another person in any media. Thus, France would likely respectively

208. Id.

209. Id.

210. Id.

211. Peter Bradshaw, The First Thing You See by Grégoire Delacourt Review - the Novel Scarlett Johansson Tried to Ban, THEGUARDiAn.com (SEPT. 9, 2015), [https://perma.cc/WN673PJG].

212. Id.

213. Willsher, supra note 205.

214. Id.

215. Id.

216. Logeais, supra note 190, at 519-20.

217. See supra Part IV. of this Note (freedom of expression in a creative work is an affirmative defense).

218. Bradshaw, supra note 211.

219. Id. ("The author all too clearly had his eye on a juicy movie deal for this high-concept romp - he even has a romcom-type 'montage' of happy memories just before the end - and I suspect he hoped that Johansson would be a good sport and play Foucamprez herself.").

220. Id. 
require consent to create or publish a digital hologram of Johansson, since the hologram projection is simply another emerging media. Analysis also depends on how apparent the identity of the person is in the image. ${ }^{221}$ The more universally recognizable the individual is, the less the portrayal needs to be identical in order to require consent. ${ }^{222}$ In the instance of a convincing replicated hologram, Johansson would be readily recognizable, and thus require consent.

\section{RECOMMENDATION FOR FEDERAL RIGHT OF PERSONALITY}

The U.S. should provide a higher level of scrutiny and absolute protection for a person's likeness when it is an exact copy as holograms are being utilized regardless of the transformative use. Further, SCOTUS should accept one of the many petitions for certiorari questioning a state's publicity rights versus the free speech in an expressive work and hold that the absolute monopolization of a citizen's personality requires the consent of the individual being monopolized.

The United States Congress should acknowledge and enforce the right of personality founded on the Constitution and privacy rights, which additionally recognizes an economic interest in personality under intellectual property laws. To implement such an act would provide the most complete right of personality for the citizens, notice to media companies, and discourage forum shopping. ${ }^{223} \mathrm{~A}$ federal right of publicity for all U.S. citizens would protect against future evolving technology from exploiting images.

The federal right of publicity should primarily provide that it is illegal to monopolize another's personality for any economic gain. Further, such a model rule should be less focused on bright lines, as it must be based on foundational principles that may endure evolving technological media platforms and the development of creative marketing. Therefore, considerations similar to French law's consent requirements should be adopted - i.e., the more recognizable the person is in a digital portrayal, the greater the requirement of consent. When a person's likeness is reproduced with such realistic portrayals as holograms, consent should be required by contract and with specificity of time and breadth for the use of the reproduction. When consent is not given, damages should be tallied for both moral and economic claims. Until the prevalence of media manipulation and transfer over the internet, the States adequately implemented protection for citizens from exploiting personality through privacy and publicity torts. ${ }^{224}$ However, people are no longer just concerned with their printed picture like the days of Warren and Brandeis' privacy concerns.

Germany's holistic right of personality, which includes an economic interest

221. Logeais, supra note 190, at 519-20.

222. Id.

223. See Lapter, supra note 71 , at 243.

224. See generally, False Light - Misappropriation - Right of Publicity, REPORTERS COMMITTEe FOR FREedOM OF THE PRESS, http://www.rcfp.org/first-amendment-handbook/falselight-misappropriation-right-publicity (simplifying privacy torts of personality) [hereinafter REPORTERS COMMITTEE]. 
under intellectual property, is not a far reach from what the U.S. already provides (inconsistently). Generally, if the States are not implementing laws against the Constitution, the Federal government has no need to interfere. However, the many variations in the treatment of these personality invasions are no longer adequate for the extent to which such invasions are made in the current society, with evolving media technology and increased identity and privacy concerns. ${ }^{225}$ Further, media sharing happens over the internet, which is not only interstate (invoking the Commerce Clause), but international. ${ }^{226}$ Therefore, there should be a unification of expectations by acknowledging a cohesive right of personality in the U.S.

A federal right should incorporate consent requirements like those of the French droit a l'image, when the taking of another's image is as monopolizing as a hologram. French law provides a narrowly constructed consent requirement, an element which can endure evolving media technology. Consent for French use of one's image must be expressed in writing and specific in time and use. ${ }^{227}$ Additionally, consent must be given "before the taking of a person's image acting in a private context and prior to the disclosure of the image to the public, even if the image was taken in a public setting. ${ }^{228}$ For hologram purposes, the taking of one's image is the creation, or publication, of the hologram.

California's right of publicity statute provides guidance for the beginning of a workable framework for the intellectual property interest of publicity rights. Additionally, the successful right of publicity cases in the Ninth Circuit were based on the application of California's right of publicity statute. Therefore, California is the most experienced regarding right of publicity claims; and it is worth considering for application to digital hologram production of one's likeness.

The California right of publicity statute provides protection for all people in many media vehicles. It provides that "any photograph or photographic reproduction, still or moving, or any videotape or live television transmission, of any person, such that the person is readily identifiable" requires consent. Encompassing mixed media is essential to enduring technological elaborations of image use. It further provides a dollar amount if the courts have trouble finding damages. ${ }^{229}$

However, California's and other states' right of publicity statutes provide an exception for "entertainment purposes" without defining what entertainment purposes are. The exception is noted with literary purposes and should be interpreted under the artistic expression exception, or at least opposite "purposes

225. Lapter, supra note 71, at 243.

226. Id.

227. Leogeais, supra note 190, at 521.

228. Id.

229. CAL. Civil Code $\S 3344$ (West 2016) (Unauthorized commercial use of name, voice, signature, photograph or likeness). 
of trade. ${ }^{230}$ It would be more advantageous to the pro dignity position to explain the permission for use in parody which is the most likely as French law allows. ${ }^{231}$ The parody must only be in humor; because a parody by definition is not truth. ${ }^{232}$ This differentiation is significant when one considers a realistic digital hologram being animated without consent is a denial of self-determination and arguably a degradation to one's dignity.

The foundation for a right of personality already exists in the U.S. When the courts began to adopt Brandeis and Warren's privacy recommendations, they were recognizing a right of personality based on dignity similar to the holistic umbrella of the German right of personality. ${ }^{233}$ However, the courts diverged from such principles when plaintiffs improperly argued for an economic interest in privacy, which courts refused to recognize for celebrities. When the courts began to recognize an economic interest in personality, the right of publicity, it became difficult to find damages for both moral and economic interests. ${ }^{234}$ Though there is a difference in the moral and economic interests of personality, each applies to a person, whether they are a celebrity, a political figure, or prefers anonymity.

For a court to dictate an identity to which a person must subscribe at a given time represents a loss of choice. Such loss of choice is against self-determination, liberty, and dignity. Liberty and dignity are the foundation of human rights. ${ }^{235}$ Loss of choice is one of the things that the First Amendment was meant to protect against. Further, like the ECHR, freedom of expression of one author cannot take precedent over freedom to express one's personality for one's self. ${ }^{236}$

\section{CONCLUSION}

The taking of one's personality in digital hologram form is more extreme than misappropriating a photo or creating a parody of another. There is a great intimacy and loss of control in such instance. Digital human holograms that cross the "uncanny valley," should be viewed as extensions of a person and not be used in any way against the person's will. A federal right of personality for celebrities and non-celebrities in the U.S., which requires narrowly tailored consent when programmers create digital human holograms, will not conflict with the First Amendment. The rights of personality and freedom of expression can be

230. See generally Darren F. Farrington, Should the First Amendment Protect Against Right of Publicity Infringement Actions Where the Media is Merchandiser? Say It Ain't So, Joe, 7 Fordham Intell. Prop. Media \& ENT, L.J. 779, (differentiating between entertainment and merchandising).

231. Logeais, supra note 190, at 531-32.

232. Id.

233. Compare Brüggemeier, supra note 6, at 13, with Joseph A. Page, American Tort Law and the Right to Privacy, Personality Rights in European Tort Law $42-44$ (2010).

234. Madow, supra note 77, at 169.

235. McCrudden, supra note 132 , at $848-840$.

236. BARNES, supra note 1 , at 6 . 
reasonably balanced.

The creation of lifelike holograms is a highly skilled art. There may be times when the freedom of expression should succeed over a requirement of consent when recreating another person in digital form. But until one principle becomes necessarily apparent, consent should be absolutely required before a digital master like Pulse Evolution exploits human images. 